\title{
TRADITION IN THE NOVELS OF ANWAR RIDHWAN AND PUTU WIJAYA
}

\section{By Mawar Shafei}

[mar@ukm.my]

Faculty Social Sciences and Humanities

Universiti Kebangsaan Malaysia

\begin{abstract}
This paper is the result of a comparative study carried out on the novels of Anwar Ridhwan and Putu Wijaya, writers who represent Malaysian and Indonesian authorship respectively. This study focuses on the inclination of both writers to dignify "tradition" in their work. What is meant by the framework of "tradition" is that both writers source their materials mainly from traditional texts in order to construct the structure of the novels which is the object of our attention. Specifically, the novel Hari-hari Terakhir Seorang Seniman (Anwar Ridhwan) makes references to the romance Si Gembang or Teluk Bidung Kota Lama while the novel Perang (Putu Wijaya), to the classical text the Mahabharata. Aside that, "tradition" as is presented by the writers in the novels under study, has been identified to take account of the concept of tradition which is the authorship ideology of both writers - Anwar Ridhwan with his concept kampung halaman Melayu (Malay hometown), Putu Wijaya with his concept desa-kala-patra (found in the Balinese tradition). These "traditions" are anchored in their experimental works which apear to be defying convention; a predilection that
\end{abstract}




\section{MALAY LITERATURE}

clearly is in line with the authorial rhythm of these outstanding writers. The study conducted employs the intertextual framework as well as dialogism advanced by Mikhail Bakhtin and Julia Kristeva; a framework for observing authorship processes that is directed towards the effectiveness of creation theory. The study finds that both writers conform to the cultural traditions of their people, are clearly appreciative of these traditions, perfom meaning inversions in the novels examined (the hypertext) which are not evident in the pre-existing text (the hypotext).

Keywords: Anwar Ridhwan, Putu Wijaya, the novel Hari-hari Terakhir Seorang Seniman, the novel Perang, intertextuality, tradition.

\section{Introduction}

The Malay novels published within the first few decades of the birth of the genre in Malaya in the 1920's, clearly exhibit a structural inclination towards traditional prose, such as the lipurlara (romances) or the hikayat (legend). Examples of this leaning towards traditional elements are: the retention of the word hikayat in the titles of novels, the preservation of the plot pengembaraan (journey), the use of hyperbolic and idealistic settings, the depiction of uebermensch or superman characters, and the incorporation of syair (a rather long poem made up of a number of verses, each verse consists of four lines) and pantun (a poem, typically a quatrain, the first line rhymes with the third, the second with the fourth). For instance, Hikayat Faridah Hanum incorporates all these elements, most of which are usually found in romances such as Hikayat Malim Dewa and Hikayat Anggun Cik Tunggal.

In the context of this study, the inclination towards tradition is examined in the novels penned by Malaysian writer Anwar Ridhwan, and Indonesian writer Putu Wijaya. They are among writers who are oriented towards alluding to earlier/synchronic texts in the work they produce (Mawar Shafei, 2010). Both are established writers who represent the literature of their own countries with their experimental methods. Anwar Ridhwan who won the SEA Writes Prize 2002, was recently named Malaysia's 10th National Literary 
Laureate; likewise, Putu Wijaya was the recipient of the SEA Writes Prize in 1980. It is evident that these writers still closely adhere to the structure of traditional text particularly in their novels, such as Hari-hari Terakhir Seorang Seniman and Perang. Hari-hari Terakhir Seorang Seniman, the first novel written by SN Anwar Ridhwan, highlights the conflict within its protagonist, Pak Hassan, who pursues a career in story-telling despite the objections of his younger brother. Upon the death of their father, Pak Hassan and his younger brother come into the legacy left by their father; Pak Hassan was bequeathed a rebab bertali tiga (a three-stringed musical instrument resembling a mandolin), while his younger brother, a tract of paddy land. Following a conflict that arises between them, Pak Hassan leaves his kampong, journeying south where he meets Selamah. Pak Hassan then "migrates" to Desa P.S. together with Selamah and their first-born, Senah. Pak Hassan is faced with all kinds of hardship after the death of Selamah [who dies giving birth to their second child, Mat Junuh]: Senah is violated and later runs away; soon after Mat Junuh too runs away. The mental anguish Pak Hassan suffers manifests itself in the stories he recounts, and he meets his end as a result of it.

The novel Perang by Putu Wijaya, meanwhile, is divided into two parts, "Musuh" (the Enemy) and "Goro-goro". "Musuh" is set against the backdrop of life in kayangan (the land of the gods and godesses) and features characters such as Prabu Yudistira, Bima, Semar and his children Petruk, Gareng and Bagong. They are citizens who support the Amartas or Pandawas. Other characters also featured in the novel are Arjuna and his children, Abimanyu and a number of chieftains such as Sadewa, Gatotkaca and Nakula. This group are hostile towards the people of Astina or Korawa, who are led by Suyudana. Among the characters from Korawa are Bisma, Sengkuni, Adipati Karna, and Begawan Dorna and his child, Aswatama. A war which is not planned by the gods, breaks out between the two groups. The war is caused by a misunderstanding on the part of the Amartas who are under the impression that the arrival of reinforcements from Astina sent to cope with a natural disaster, is a pra-Bharatayuda attack. However, both parties agree on a reconciliation and decide to hold a celebration at the border. 
This takes place after Sangkuni gives a different interpretation of the Pandawas' mission to apologise to the Korawas. "Musuh" (the Enemy) ends with the two parties, who, after realising that they are blood relations, reach an agreement and pledge to be on good terms in order to oppose the plans of the gods. "Garo-garo", meanwhile, focuses on the Semar family which is divided into two groups, Semar Jawa and Semar Bali. In this second part, the writer introduces the story of Semar in the broader context of life as it is today in Indonesia.

This study examines the inclination of both writers to allude to tradition in their work. What is interesting is the actual form of "tradition" involved. This leads us to the implications and appropriateness of the references made to tradition in the novels under discussion, and the significance behind this. In order to present the processes, form and appropriateness of the references to "tradition" made by both these great writers, Bakhtin's and Kristeva's framework of intertextuality are combined in the best possible manner.

\section{The Framework of Intertextuality}

The predisposition of both texts to refer to traditional hypotexts, is closely examined based on the process or concept of intertextuality forwarded by Mikhail Mikhailovich Bakhtin whose basic ideology centres on the dialogics that between two texts, there exists a relationship (Allen, 2000:20-22). This process is discussed within the framework of a comparative investigation in which Hari-Hari Terakhir Seorang Seniman and Perang, both hypertexts (a hypertext is a later text that results from the processes of intertextuality), are set off against the relevant traditional texts or hypotexts (a hypotext is an earlier text referred to produce a hypertext).

The hypotext-hypertext relationship within the framework of this discussion, takes off from Bakhtin's dialogic ideology which hypothesises a relationship between any two given texts, or a "dialogue" between an existing text and a prior text it in the archive of the literature itself. Bakhtin juxtaposes the concept "dialogue" or "heteroglossia" (another term he uses for the same concept) ${ }^{1}$ with "monologue". According to Bakhtin's ideology, dialogics or heteroglossia is a manifestation of the multidimensional nature of 
language (the metalanguage), that is, everyday social utterances or rhetorics (socio-ideological language). In fact, these utterances, which form the basis of the larger discourse, are not independent of other utterances (monumental, Bakhtin and Volosinov, see Allen, 2000:19); they are bound to previous utterances. On the other hand, monologue or monologics is just the reverse; it is a single voice in a linguistic structure.

According to Bakhtin, a literary work does not represent the original thoughts of its author, rather, it is a conflation of various forms of relations. Bakhtin posits that the system of signs, after Ferdinand de Saussure, is non-unitary, "unstable", involves relational units and the concept "similarity-dissimilarity", and lastly, embodies the concepts dialogics and intertextuality. It is generally believed that the theory of intertextuality results from the early works of Swiss linguist, Ferdinand de Saussure, when he discussed the notion of differences in the linguistic sign in a collection of his lectures titled Course in General Linguistics (1915). Saussure zeros in on the basic issue, the linguistic sign, which is represented by two elements, the signified and the signifier. The "linguistic sign" is not a word or a meaning that refers to something in the outside world, instead it is the "combination and compatibility" between a "concept" and a specified signifier. There is no sign that can denote meaning on its own. Thus, Saussure perceives the existence of the phenomena "relations" and "differences" in the linguistic sign. Each sign exists in a system and generates meaning when it is put through the process of comparison with other signs.

Julia Kristeva notes that dialogics directs us to the phenomenon vraisemblable, that is, the relation or binding (dialogue) between the world of imagination or creativity (internal text) and the real world (external text). Writers do not create works from their own original thoughts, instead compile pre-existing texts comprising "individual texts" and "social texts". Therefore, a given text is not an isolated object or singular in nature, instead it is a collection of cultural texts. This is in keeping with Kristeva's opinion that "...a permutation of texts, an intertextualtiy in the space of a given text ... several utterances, taken from other texts, intersect and neutralize one another" (Allen, 2000:35). The creative process of an author proceeds from much earlier texts which are put through several processes of transformation, absorption or citation. Thus, 
Kristeva sees a text as having been constructed from a mosaic of ealier texts and details out the processes that take place, the manner in which they happen and the reasons the author chooses to have them happen. An analysis of a text is to be grounded in the dichotomy of structural elements (internal text) such as theme, plot, characterisation, settings and style of writing, and elements exterior to the structure (external text) such as history, culture and religion. Kristeva perpetuates Bakhtin's dialogics under the new name "intertextuality". Several other well-known writers continue to debate the relations of dialogue between texts, for instance, Barthes, Gerard Genette, Michael Riffaterre and Harold Bloom.

\section{A Comparative Analysis}

The comparative dimensions focused on in both novels under investigation are: (1) both writers choose to examine traditional texts, (2) the concept of "tradition" upheld, as well as the variety of intertextual processes that occur between them.

\section{(i) Traditional Texts in Hari-hari Terakhir Seorang Seniman}

The character, Pak Hassan, as a story-teller in Hari-hari Terakhir Seorang Seniman (1979) signals Anwar Ridhwan's inclination towards traditional text. Romance as a genre of folk literature is clearly subscribed to by the author with the insertion of the text Si Gembang or Teluk Bidung Kota Lama in the stories told by Pak Hassan. ${ }^{2}$ This is evident when the protagonist, Pak Hassan, begins telling the story in Chapter 2. This folklore is carried over into Harihari Terakhir Seorang Seniman in seven parts; starting from part one of Chapter 2 (pg.13),

(Duduk bersila sambil bersandar ke dinding, dia menceritakan) kisah kelakuan anak angkat Tuk Raja Berdura Besaryang bernama Kuncam Perang Gelombang Perang Alun Tujuh Gelombang Tujuh mengambil bayi yang baru dilahirkan oleh Puteri Manik Urai isteri Tuk Raja Berdura Besar, lalu satu tembuninya dibuang ke baruh dalam pohon piya bersama bayi tersebut dan satu lagi tembuninya dicampak ke dalam laut ...

(Sitting cross-legged with his back against the wall, he begins to 
tell) the story of the stepson of Tuk Raja Berdura Besar named Kuncam Perang Gelambang Perang Alun Tujuh Gelambang Tujuh, who abducted the newborn baby of Puteri Manik Urai, the wife of Tuk Raja Berdura Besar, causing one part of his placenta to be flung into a piya tree in the lowlands together with the baby, and another part into the sea ...

Si Gembang is the story of a state known as Teluk Bidung Kota Lama which is under the rule of Tuk Raja Berdura Besar and his consort, Puteri Manik Urai (Figure 1). Owing to a deep-seated jealousy against Si Gembang who is prophesied to become famous and endowed with supernatural powers, his placenta is thrown, one part into the lowlands and the other into the sea. The piece of placenta in the lowlands (Si Gembang) and the one in the sea (Awang Selamat) are discovered by Tun Raja Lang and Puteri Manik Urai who take them in and treat them as their own. Once he is a young man, Si Gembang rears a very special rooster called Sitam. Conflict develops when Kuncam enters his rooster in a cockfight against the rooster of Megat Jenal from Terengganu. Kuncam's rooster loses in the fight and Kuncam is forced to hand over Negeri Teluk Bidung Kota Lama, which is the stakes, to Megat Jenal. Seperah Muda tries to regain the country which once belonged to his father, by searching for a rooster that is able to defeat Megat Jenal's. Seperah Muda meets Megat Gembang and Sitam. Megat Jenal's rooster is finally trounced by Sitam. While visiting the family of Tuk Raja Berdura Besar, Kuncam's secret (throwing Si Gembang's placenta one part into the lowlands and another into the sea) is revealed. Kuncam and the astrologer who made the false prophecy are punished. The story has a happy ending; Si Gembang marries Cik Siti Jarum Bergiling from Negeri Serendah, who is invested with supernatural powers.

Theassimilative relations of hypotext to hypertext is demonstrated when Pak Hassan associates Mat Junuh with Megat Gembang; when Selamah"s experience of giving the birth to Mat Junuh during which part of his placenta is retained which then becomes the cause of Selamah's death (pg. 8) is alluded to the birth of the son of Raja Teluk Bidung Kota Lama and the cruel disposal of his placenta in "Si Gembang". 


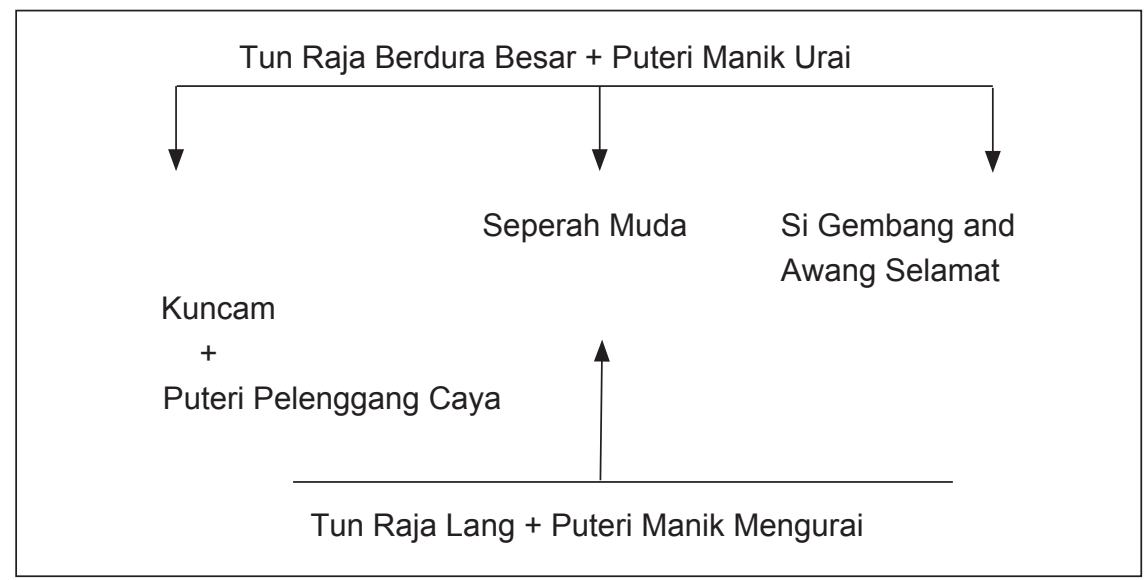

Figure 1 The Relationship between the characters in the Hypotext $\mathrm{Si}$ Gembang.

The author employs the technique "flashback" in this episode as is evident on pages 13-14,

Pada saat itu, sebahagian daripada fikirannya terlontar ke masa lampau, pada suatu pagi beberapa jam sesudah selamah melahirkan Mat Junuh. Setelah menanti sekian lama tetapi sebahagian tembuni Mat Junuh belum keluar juga, akhirnya dia berkata kepada bidan Mariam, kata-kata yang dia sendiri tidak tahu sama ada bayangan dukacita, sesal atau kecewa. "Saya hendak tanam mana yang ada dulu, Mak Cik Mariam. Yang terbit kemudian saya tanam kemudian, mungkin menghala ke arah laut. Itulah yang terjadi, lebih kurang kepada tembuni Megat Gembang ..." Mula-mula bidan Mariam tidak faham apa yang lelaki itu perkatakan, tetapi apabila dia sudah mengerti, dia cuma menggeleng-gelengkan kepalanya.

At that moment, his mind flits back to bygone days, to a morning several hours after Selamah had given birth to Mat Junuh. After waiting for some time and part of Mat Junuh's placenta was still lodged in Selamah's womb, he finally spoke to the midwife, Mariam, words that reflected emotions he himself could not put a name to - sadness, regret, disappointment? "I would like to bury whatever part of it that has been removed, Aunt Mariam. Whatever comes out later, I will bury later, perhaps facing the sea. That was 
what happened to the placenta of Megat Gembang ..." At first, midwife Mariam did not understand what the man was saying, but when she did, she merely shook her head.

\section{[ii] Chapter 2: 15,}

(cerita pada malam berkenaan ditangguhkan pada) waktu ayam Megat Gembang yang diberi nama Sitam terbang balik menemui Megat Gembang. Tahulah kepada putera Tuk Raja Berdura Besar yang semasa kecilnya terbuang dalam pohon piya, bahawa di bong sedang terjadi sengketa. Sengketa antara Separah Muda yang mempersabungkan Sitam dengan Megat Jenal yang ayamnya telah pun luka dalam persabungan bertaruhkan negeri Pelenggang Caya.

(the story-telling that night ended at) the point where Megat Gembang's cockerel, called Sitam, flies back to him. The prince who is the son of Tuk Raja Berdura Besar, who when he was born was thrown into a piya tree then realises that a conflict has taken place in the cockpit. The conflict between Separah Muda who pits his cockerel, Sitam, against that of Megat Jenal, whose cockerel is wounded in the cock-fight for which the wager is the state of Pelenggeng Caya.

Further examples of assimilative relations demonstrated by Anwar Ridhwan are: the relationship between the image of Selamah and that of Tuan Puteri Selamah, and the image of Senah and that of Raja Senah Alun Tujuh Belundang Tujuh Seperang Belundang Perang; the similarity between the affliction suffered by Tuan Puteri Selamah and Selamah after the latter had given birth to Mat Junuh; "losing" Negeri Teluk Bidung which belongs to Tun Raja Berdura Besar to Megat Jenal, and for Pak Hassan, "losing" Selamah, Senah and Mat Junoh in his life.

\section{(ii) Traditional texts in Perang}

In the novel Perang, names such as Korawa, Pandawa and Bharatayuda brings forth the deja vu effect reminiscent of the Mahabharata. This is more keenly felt when bitter enmity such as that between the Korawas and the Pandawas becomes one of the main themes in the novel. The Mahabharata is a Hindu epic that is said to have been in existence since $300 \mathrm{BC}$ or so and is among the 
longest epic in the world. It comprises eighteen books or chapters ("eighteen" signifies the number of days the war was fought) and an appendix of 1,375 Harivamsaparva verses by Vyaasa. The Mahabharata is available in many versions. ${ }^{3}$

The Mahabharata means "the great Bharata story"; the Bharatas are the early ancestors of two warring factions, the Pandawas and the Korawas. What starts as issues relating to family ties and love, later degenerate into power struggles, sibling rivalries, jealousies, and bad blood between the two factions, the Pandawas and the Korawas (Figure 2 shows the genealogy of the Bharatas).

Both the Pandawas and the Korawas are provided with the knowledge and training in martial valour. Throughout the training, the Korawas and the Pandawas would usually compete with each other to the extent that the training sometimes ends in dispute. This conflict persists until they reach adulthood. The grudge nursed by the Korawas deepens when the Pandawas has the support of the people of Hastinapura to continue ruling their country. Yudistira is finally crowned Raja Indraprasta (Amarta). His government enjoys good relations with several countries such as the Kingdom of Dwaraka (Dwarawati) whose ruler Raja Kresna (Batara Kresna), is appointed adviser. Nevertheless, the Pandawas are later caught in a deceitful trick in a game of dice engineered by Sengkuni, an a confederate of the Korawas. As punishment, they are made to live in the jungle for twelve years.

Once they have completed serving their sentence, the Pandawas make several attempts at reconciliation. However, the Korawas, specifically Duryudana, firmly resists these attempts and prepares for war although he knows about the Bharatayuda ${ }^{4}$ effect which would wipe out the entire Korawa faction. Arjuna and Duryudana then pay Batara Kresna a visit to appeal for reinforcements. After the selection process, Duryudana is given 10000 armed soldiers, while Arjuna chooses to request for assistance from Batara Kresna himself; Arjuna believes that the strength and efficacy of the Pandawas come from the counsel and guidance of Batara Kresna.

The Bharatayuda War is fought in Tegalkuruksetra (Kurusetra) for eighteen days. As planned by the gods, the Pandawas win the civil war. The kingdom of Hastinapura is later governed by the grandson of Arjuna, Parikesit, for sixty years before he is succeeded by his son, Prince Janamejaya. 


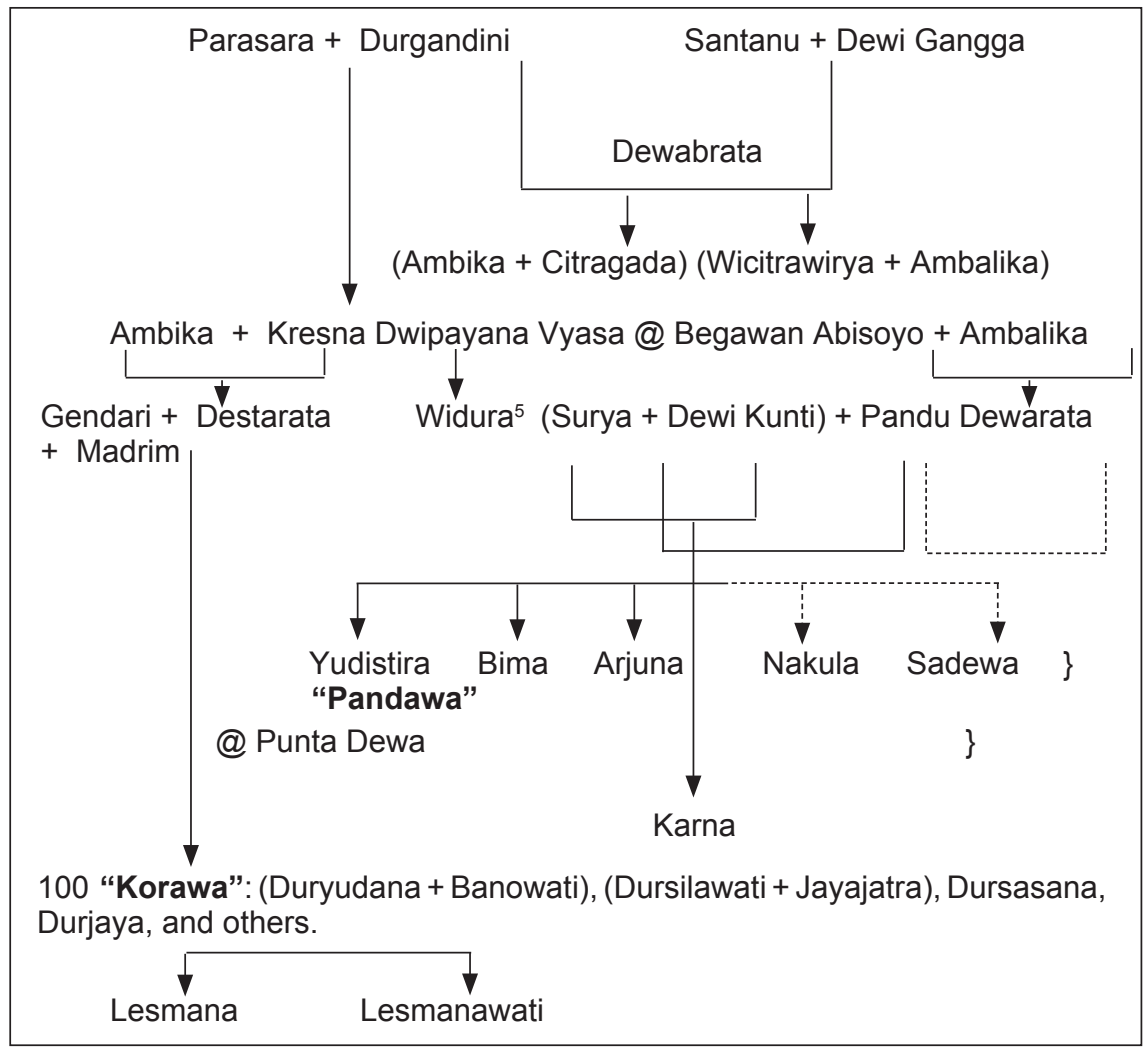

Figure 2 The Genealogy of the Bharata Dynasty in the epic Mahabharata.

Adhering religiously to the narrative structure of the Mahabharata and having sound knowledge of each character involved has clearly helped link the hypotext with the hypertext, in the context of this study, the plot, the background and the characters in the novel Perang. As early as in chapter 1, apart from displaying the background of enmity between the two factions, the Pandawas and the Korawas, the author clearly implements expansion on the principal subject from the hypotext, that is, the "enemy". The role of the principle once put forward by Riffaterre is manifestly evident in the episode where Semar expands the meaning of "the enemy" to denote,

... alat pendidikan jiwa raga. Kita jadi siap, awas dan mawas diri selalu. Untuk melatih kita menang. Untuk mengasah pikiran 
kita sehingga tidak alpa, tidak macet, tidak ceroboh. Musuh itu harus kita pelihara seperti kebun di belakang rumah kita, yang membuat kita sibuk, sehingga tidak kesal menunggu, tempat kita menyalurkan tenaga waktu senggang. Kita harus berterimakasih kepada musuh-musuh itu, biarkanlah dia memiliki ruang hidupnya di dalam perkarangan kita ... para empu yang ilmunya setinggi langit pun, memelihara musuh para empu yang tak kalah bobot peradabannya. Dengan bermusuhan mereka terus menuntut ilmu, saling mengasah diri ... menang itu susah ... kita terpaksa harus pelihara musuh. Musuh itu pada hakikatnya sekolahan kita ....(hlm. 7)

... a tool for educating the soul. We must be prepared, vigilant and introspective. To train us to win. To sharpen our minds so that it is not neglectful, congested, or imprudent. We must take care of our enemies the way we look after the vegetable plot in our backyard, a place for us to channel our energy in our spare time, which keeps us busy, such that we are quite happy to wait. We should be thankful to our enemies, allow them to own a small living space on our premises ... mastercraftsmen whose knowledge reach up to the heavens too take care of their enemies who are no less cultured than them. By remaining each other's enemies, they continue to seek knowledge, each honing his skill ... it is not easy to win ... we must look after our enemies. The enemy in reality is our training ground ... (pg. 7)

The processes of expansion and "paradigm shift" show that the enemy should no longer be viewed stereotypically. The concept "enemy" is tendered by the author as an index of his hope to assign a wider meaning to "enemy" than is done in the hypotext. The enemy is not restricted to the enemy in the Pandawa-Korawa context, conversely, the definition of "the enemy" goes beyond that, and in fact, brings with it some specific benefits. As a whole, it is clear that Perang as a hypertext from the epic Mahabharata is no longer centred on the dichotomy between truth and falsehood, as it is in the hypotext. On the contrary, the author combines the processes of intertextuality such as expansion, replacement and diversion to suggest a meaning shift in the word "enemy" which is the central issue in Perang.

It is evident that both authors bring back the traditional text, "folklore" and epic, into their novels. Anwar Ridhwan opts for the issue of "loss" while Putu Wijaya reintroduces the issue of family 
feuds, each from their respective hypotext. Both novels are a brew of mutifarious conflicts as the author scour deep into the souls of the characters who are undergoing metamorphosis and re-creation, and create new characters/characterisation which are not in the hypotexts. Pak Hassan's suffering and mental anguish are more clearly manifest with the help of the hypotext, and this helps to strengthen the narrative structure of the novel. Putu Wijaya combines characterisation and background, transforming characters/characterisation by presenting old issues in the Mahabhrata in a new perspective. By doing so, the author is able to touch on more challenging issues such as politics and leadership, as well as comment on the attitude of his own countrymen.

\section{(iii) The concept "tradition" as an authorship ideology}

The five positive elements in the concept "hometown" put forward by Anwar Ridhwan which is related to the inclination towards "tradition" (1999:14-21) are,

(a) life is centred on and revolves around the religion and culture of one's forefathers,

(b) wisdom is necessary for the individual, family and society to play a role and respect each other's rights,

(c) Nature should be utilised with great care, preserved and developed for the future generation,

(d) one's honour is a right that must be defended and

(e) the rich have a responsibility towards the less fortunate.

Some of the above elements are present in Hari-hari Terakhir Seorang Seniman, for instance, man still conform to the tradition of their forefathers and abide by their religious laws, they defend their honour and attempt to balance life around them with their personal desires. As a consequence of their obedience to this concept, man live in peace physically and spiritually.

This concept of "tradition" is a clear indication of Anwar 
Ridhwan's departure from the leanings of the literary movement Asas 50. By employing writing techniques culled from the West, Anwar succeeds in "locking himself in" under the identity "postAsas 50". ${ }^{6}$ It shows his appreciation of the traditional heritage of Malay literature; to refer to, apply, present, and conserve its role in producing a modern literary text. What is clear in the novel is that Anwar Ridhwan displays his skill at fathoming the character of old man Pak Hassan, understanding his feelings, his thinking, by combining the narrative plot with hypotextual conflict. It is evident that through the process of intertextuality, the author is able to portray Pak Hassan's closeness to God and nature, his love for humankind, and his ability to preserve his integrity despite being left to live alone.

Putu Wijaya, manifestly employs meaning transfer in a big way; he gives a new interpretation of the word "enemy", one that is more comprehensive, by performing a paradigm shift and meaning transformation. The author executes all manner of metamorphosis, re-creations and conjures new characters/characterisation that are not found in the Mahabhrata. By doing so, the author touches on issues that are more challenging such as those relating to politics and leadership, as well as the attitude of his own countrymen. Based on the examples from his work and his authorship ideology, it can be safely concluded that the intertextual manipulation effected by Putu Wijaya is part of the concept of desa-kala-patra which he subscribes to. Technically, the process of meaning transfer from hypotext to hypertext accords with Putu Wijaya's opinion regarding the role of traditional literary works such as the Mahabharata/shadow play which is saturated with moral instructions, discipline and dynamics; they are not solely incorporated for commercial reasons such as what happens in most shadow plays now in Indonesia.

The final pages of his novel Perang are littered with "surprises" which go against convention and in a way offer more evidence to the readers who have been closely following his authorship. It also is an echo of the statement made by Putu Wijaya about how much he wants to be a "teroris mental" (intellectual terrorist) in each of his work,

... saya menjadi "teroris" ketika menulis. Kerana itu konsep berkesenian saya adalah teror mental yang dibungkus anekdot. 
Saya menginginkan kesenian saya jadi bom-bom anekdot Molotov yang menggigit batin. Untuk mendongkel segala fikiran yang macet dan membuka alternative. Mencubit orang yang sudah terlena atau mabuk, mungkin juga mati rasa di dalam kehidupan, agar tersadar kembali, lalu mempertanyakan sekali lagi tindakantindakan dan sikapnya.

... I am a "terrorist" when I write. Because of that the concept I uphold in literature is "intellectual terrorism" swathed in anecdotes. I want my art to be anecdotal Molotov bombs that pierce the soul. In order to unclog congested minds and reveal new alternatives. To pinch those who are asleep or inebriated, perhaps those emotionally dead too, so that they are awake once again, and questioning themselves about their actions and attitudes.

(Putu Wijaya, 2001: 227)

\section{(iv) Tradition: Experimental works which deviate from the conventional path}

It is evident that in the chapter "Garo-garo" of the novel Perang, Putu Wijaya displays an inclination to experiment with "cerita carangan". The characters from the hypotext, the epic Mahabharata, are made to undergo transformation in terms of attitude, actions and thinking. Characters, specifically from the Semar family, ${ }^{7}$ live in the real world like normal people. They breathe, get angry, become disappointed, try to improve their lives and are faced with all kinds of conflict. In fact, from the chapter "Musuh" (The Enemy) onwards, the author creates conflict among the characters and often causes them to deviate from their true character (as described in the epic) as regards their real position and attitude (baku or established - a term used by Putu Wijaya). From the perspective of intertextuality, these experiments are regarded as a series of transformations that are sound and contain the meaning that the author wants to convey.

This meaning transfer is also buttressed by Putu Wijoyo's concept of authorship. For example, via the concept wayang carangan which he has preference for, it is possible to channel meaning transformation. Wayang carangan is clearly a part of Putu Wijaya's grand design to present a more comprehensive concept of his art, that is, the desa-kala-patra. In a discourse of his titled "Tradisi Baru" (Ngeh, 1997: 8-16), Putu Wijaya debates the position 
of the local art (in the context of this discussion, the traditional art) and the national art. Nevertheless, the local/traditional art later becomes a new art when it is viewed from a new perspective and given a new interpretation ("kebenaran baru", pg. 9). In fact, it is frequently brought into contact with the national art as well as that of other countries, in order to elevate its status. It projects itself as conventional and defines its own value system. The conflict that may arise between traditional art, the national art, and those of other countries, presents itself as "an innovation" which Putu Wijaya describes using the Balinese phrase desa-kala-patra (place-timemood), a phrase drawn on in a harmonious way. This trisula (trident) should always be a point of consideration. It is this phenomena that one is conscious of upon completing the study of Perang. Once "the enemy" in the Mahabharata has been examined, the intertextual conflicts experienced, the end result is the slow emergence of "a new truth", and the translation of new values. This time, the reassessment of "the enemy" in Perang, calls into being desa-kalapatra; based on the contextual (Indonesia) place, time and mood, the hypertext offers a meaning which is clearly more flexible and of greater relevance to the general readers who uphold it. It is in accordance with the personal opinion of Putu Wijaya himself that a theme is good if there is some form of spiritual experience to be gained from it, if it "communicates" with the readership; this is in agreement with the demands of desa-kala-patra.

Doubtlessly, Putu Wijaya rejects the stereotypical labelling of Perang as an already-written text, which is how Roland Barthes would view it. By applying some of the principles of intertextuality such as the ones proposed by Riffaterre, Putu Wijaya is able to "produce" a "new text". Manipulating his creativity to expand the hypotext and butting convention with his courage, Putu Wijaya manages to turn the space Perang into a platform to observe and consequently remedy the misadventures of the past; more so the misadventures which occurred within the fabric of his own nation. The pain and suffering of revealing the flaws in one's society that Bagong experiences when he uncovers the defects in the community under the bridge (chapter 10, titled "Garo-garo") is exactly the same as the sharp pain the Pandawas experience when they fight against and injure their own kind, the Korawas, in order to discover the true path. In the case of the Bagongs (Indonesians), after several 
debates with the Semar family, they finally agree that the dearth of awareness amongst the people is the main obstacle. Just like Semar says, "... there is no need to be higly educated. Being aware is enough. There is no need to ask them to read or to attend courses, if they can read into their future, that's enough. Once they have grasped the knowledge about who they really are, they will quietly strive to master the knowledge of living ......" (pg. 310).

Apart from perfoming several meaning inversions on a number of issues, Putu Wijaya also executes superficial inversions in Perang which as a whole, reinforces the meaning inversions. For instance, the author depicts the behaviour of the characters in the hypotext, specifically the Semar family, as that of people who are modern; there is humour in the following statements. For example, Semar asks Bagong to rest and watch television (pg. 17); Petruk listens to a walkman as he makes his way to the Amarta to attend a conference (pg. 18); or Bagong's happiness as he goes on a threeweek vacation with a famous actress in Bali, Tokyo, Hong Kong and Singapore ("Goro-goro" chapter 9). Putu Wijaya makes the following observations (2001: 228-29) about the use of humour,

Hanya dengan lelucon dan sesuatu yang "kabur" kita dapat berbicara dengan bebas dan keras, baik dengan teman atau musuh, juga dengan orang yang lebih pintar dan lebih bodoh dari kita, tanpa merosak keseimbangan. Lelucon dan "kekaburan" lalu menjadi strategi kebudayaan saya. Konsep berkesenian semacam ini, memang sulit untuk popular dan harus menanggung kecaman bahawa ia membingungkan, mengada-ngada, meniru-niru, membikin pusing, "tidak kontekstual", tidak memiliki komitmen sosial, tidak berguna, tanpa kedalaman, terasing dan sebagainya. Itu risiko yang harus saya terima dengan dada lapang.

Only with humour and something that is "vague" can we discuss things freely and firmly, be it with friends or foes, or with someone smarter or stupider, without upsetting the balance. Humour and "vagueness" are the strategies in my culture. The concept of involving oneself in an art such as this - it is difficult to be popular, and one must be prepared for critcisms - it is confusing, pretentious, not original, bewildering, "not contextual", not showing any social commitment, useless, lacking depth, isolated and so on. That is the risk I have to accept with a heart free from care. 
It is also part of the concept "bebagrigan" in Balinese traditional theatre. This concept, among others, features well-known characters of wayang purwo (shadow play) as having the characteristics of normal human beings, sometimes introducing surprises or creating havoc; precisely resembling theatre of the absurd. Present also among the characters, are objects or subjects alien to the art form, for instance, the examples given ealier of characters such as the "famous actress" and objects such as "the television", "walkman" and the backdrop of Bagong's holiday - Bali, Tokyo, Hong Kong and Singapore. Putu Wijaya is of the opinion that the advantage of the bebagrigan is that issues and pesan cerita (message of a story) can be presented in a more intimate way. Putu Wijaya is also of the opinion that the bebagrigan is the symbol of the debut of native theatre in Indonesia (1997: 246-47).

For Anwar Ridhwan, on the other hand, going back to "tradition" is a way of demonstrating his appreciation of the traditional heritage of Malay literature; referring to, applying, representing and conserving his role in the writing of a modern literary text. This is proven through a number of processes such as transformation, improvement, new creations and similarities from the folklore Si Gembang or Teluk Bidung Kota Lama to the novel Hari-hari Terakhir Seorang Seniman. What is clear in this novel is that, Anwar Ridhwan displays his skill at fathoming the character of old man Pak Hassan, understanding his feelings, his thinking, by combining the narrative plot with hypotextual conflict. It is evident that through the process of intertextuality, Pak Hassan's agitated mind and his sufferings are more clearly manifest with the support of the hypotext and this further strengthens the narrative structure of the novel.

As a whole, both writers proceed from the concept "tradition" in the creation of a literary work. Anwar Ridhwan abides by the concept kampung halaman (hometown) which he believes is the dominant factor in the balance of life. Likewise, Putu Wijaya believes that desa-kala-patra is able to offer a new perspective to a particular issue in the present environment. 


\section{Conclusion}

This study presents the inclination of both writers, that is, Anwar Ridhwan and Putu Wijaya, to combine the processes of intertextuality in their novels. Through these processes, they display certain similarities, (i) they both refer to pre-existing traditional texts, that is, the folklore Si Gembang or Teluk Bidung Kota Lama for Anwar, and the epic Mahabharata for Putu Wijaya, and (ii) they both refer to the traditional concept kampung halaman or desa-kala-patra besides displaying the combination of various processes of intertextuality. Clearly, the use of a traditional text as a hypotext in the creation of a novel shows the importance of the hypotext referred to and qualifies it to be considered as the agency of sign and meaning to the hypertext. Apart from that, the use of a traditional text in the creation of a novel signifies the author's appreciation of the literary heritage of his people, prevents traditonal texts from gathering dust, and results in them being re-examined and given a place in the form of numerous interpretations. The tendency to use traditional text as a hypotext is supported by the concept "tradition" which is upheld by both writers in this study. They operate on the authorship principle that when traditional values are preserved the result will be a life that is peaceful and secure. Nevertheless, as creative writers, both choose to present the concept "tradition" by employing various techniques that are heavily experimental in nature and totally unconventional.

\section{Notes}

1 In the Greek language, hetero means "other" and glot means "tongue"or "voice". Heteroglossia is a word that denotes multiple voices, the lone voice and other voices. It is also what Bakhtin refers to as "doublevoiced" discourse; in fact, several other terms are also used, for instance hybrid and poliphony. See Allen pg. 25.

2 It is an oral folklore told by Nik Abdul Rahman Nik Dir, as (Tok Dalang) a narrator and puppet master of wayang kulit, royal medicine man and a story-teller. See Mohd Taib Osman and Abu Hasan Sham in Warisan Prosa Klasik, 1984, edited by Abdul Rahman Arshad. See Abdul Rahman Haji Arshad, "Satu Kajian Terhadap Cerita-cerita Rakyat Melayu dengan Berpandukan "Si Gembang: Satu Cerita Rakyat dari Kelantan”, Universiti Malaya, 1961. 


\section{MALAY LITERATURE}

3 This study uses the version by Saleh, published by Balai Pustaka, 1958. It comprises seven chapters (1) Santanu, (2) Pandu and Drestaratya, (3) Pandawa and Korawa, (4) Para Pandawa of Indraprasta, (5) Undergoing Punishment for 12 years, (6) Baratayuda, and (7) After the Battle of Baratayuda. See Putu Wijaya's e-mail dated 23 September 2004 in which he stated that no version of the Mahabharata was specifically used as the hypotext of Perang. Nevertheless, Putu Wijaya loves to watch cerita carangan, that is, wayang tales that are not derived from the established epic, Mahabharata, rather are written and developed by the puppet masters of Java such as that produced by D.Djajakusuma, a film director in Senen Raya. Djajakusuma has written many wayang stories which are featured in magazines such as Zaman (1980-1985), when it was headed by Putu Wijaya. Efforts are now being made to compile these cerita carangan in Solo, and Putu Wijaya sees the importance of this. Cerita carangan are not sourced from established stories; only the characters in the Mahabharata are used in order to develop the story line. For example, the episode in which Bima looks for Prawitasari water which he finally finds, is a wayang tale that is interlaced with elements of Javanese mysticism. It is this inclination that becomes the mould for Putu Wijaya to create Perang.

4 In Java, it is widely known as Bharatayuda Jayabinangun. The war, among others, was waged to wipe out evil in the world. Thus, it is a war that has been "preordained" by the powers in heaven.

5 As a result of Kresna Dwipayana Vyasa's relationship with a servant, Datri. This servant had disguised as Ambalika.

6 See Kuliah II "Warisan Unsur Budaya Positif dan Ancaman Sejagat" presented on 17 November 1995 at the Osaka International Cultural Exchange Center, Japan. See Jatidiri Pasca ASAS 50, Dewan Bahasa dan Pustaka, Kuala Lumpur, 2000.

7 The characters in the Semar family are characters from the wayang purwo/kulit (shadow play) of Indonesia. Thus, in the novel, the author has hybridized the hypotext, the epic Mahabharata with aspects of the shadow play. Nevertheless, this study still treats the epic, Mahabharat, as the hypotext as it is its original source. In addition, based on the concept of wayang carangan upheld by Putu Wijaya, there is no specific hypotext that is drawn on. As for the characters, they are depicted as, (1) Petruk who is cross-eyed, has a long nose and a wide mouth. He is cheerful and loves to joke. Petruk is fond of 
wearing the sarong, kain dhagelan, and always carries a golok (a type of cutlass) and a keris sengkalan also known as uleg-uleg (a type of Javanese kris). This character, for a time rules Ngrangcangkencana under the designation Helgedul-bek; (2) Gareng is also cross-eyed, has a round nose, and always wears a chain around his neck and the sarong, kain rapekan lawak (dhagelan). Gareng is quiet, always uneasy and is rarely willing to admit his mistakes. Gareng rules Paranggumiwang for a period of time, under the title Pandugergola; (3) Bagong has prominent big round eyes, a flat nose, long and thick lower lip, a bald head and a protruding stomach. Bagong usually wears a bangle and the sarong rapekan dagelan. For further reading, see Hardjowirogo, Sejarah Wayang Purwa, 1989 and http://www.indo. net.id/mbs/mayapada indah wayang golek.htm

\section{References}

Abdul Rahman Bin Haji Arshad, 1961. "Satu Kajian Terhadap Cerita-cerita Rakyat Melayu dengan Berpandukan Si-Gembang Satu Cerita Rakyat dari Kelantan". Latihan Akademik, Kuala Lumpur: Universiti Malaya.

Allen, Graham, 1999. Intertextuality. London: Routledge.

Anwar Ridhwan, 2000. Jatidiri Pasca ASAS 50. Kuala Lumpur: Dewan Bahasa dan Pustaka.

Cuddon, JA, 1998. Literary Terms and Literary Theory. London: Penguin Books.

Mawar Shafei, 2004. "Naratif Ogonshoto dengan Spektrum Multidisiplin" in Jurnal Pangsura Julai-Dis. 2004. Brunei: Dewan Bahasa dan Pustaka.

Mawar Shafei. 2010. Novel Intertekstual Melayu. Bangi: Penerbit UKM.

Mohd Taib Othman \& Abu Hassan Sham, 1984. Warisan Prosa Klasik. Kuala Lumpur: Dewan Bahasa dan Pustaka.

Putu Wijaya, 1997. Ngeh: Kumpulan Esai Putu Wijaya. Jakarta: Pustaka Firdaus.

Putu Wijaya, 2001. Sang Teroris Mental: Pertanggungjawaban Proses Kreatif. Jakarta: Yayasan Obor Indonesia.

Rahman Yusof, 1988. "Realisme dan Metafiction dalam Cerpen-cerpen Anwar Ridhwan" in Dewan Sastera Ogos: 59-62. 
MALAY LITERATURE

Sigit B. Kresna, 2001. Putu Wijaya: Sang Teroris Mental. Jakarta: Yayasan Obor Indonesia.

Th. Sri Rahayu Prihatmi, 2001. Karya-karya Putu Wijaya: Perjalanan Pencarian Diri. Jakarta: Penerbit PT Grasindo.

Worton, Michael \& Still, Judith (ed.), 1990. Intertextuality: Theories and Practice. St. Martin's Press. 